Pathologe 2008 · [Suppl 2] 29:314-316 DOI 10.1007/s00292-008-1049-4

Online publiziert: 7. September 2008

(c) Springer Medizin Verlag 2008

M. Tinguely ${ }^{1}$ A. Hofmann ${ }^{2,3}$ - D. Bausch-Fluck ${ }^{2,3}$ - H. Moch ${ }^{1}$ - B. Wollscheid ${ }^{2,3}$

${ }^{1}$ Institute for Surgical Pathology, University Hospital Zurich, Switzerland

${ }^{2}$ Institute of Molecular Systems Biology, ETH Zurich, Switzerland

${ }^{3}$ NCCR Neuro Center for Proteomics, ETH and University of Zurich, Switzerland

\title{
Immunophenotyping without antibodies
}

\section{New perspectives for lymphoma characterization}

The current WHO classification of haematopoietic neoplasms integrates genetic and chromosomal aberrations as well as consecutive protein changes [2]. Haematopoietic neoplasms are mainly defined morphologically according to their normal counterpart in reactive lymphoid and bone marrow tissue. However, many overlapping histological features exist in cancerous tissue, making antibody-based techniques indispensable to classify lymphomas and to increase diagnostic accuracy. Immunohistochemistry (IHC) is the most important method in routine diagnostics today. Although antibody-based methods allow lymphomas to be classi- fied to a certain extent, there are still many "grey zones" with overlapping morphological and immunophenotypic features, making it difficult to determine lymphomas exactly $[6,7]$. Moreover, among the currently available markers used, prognostic and predictive protein markers are still scarce, and the present classification seems inadequate in predicting the outcome of each lymphoma type $[3,4,5]$.

The molecular composition and dynamic organization of the plasma membrane (PM) determines how a cell can interact with its environment at any given moment [9]. The identification of predictive and diagnostic PM markers for cancer is

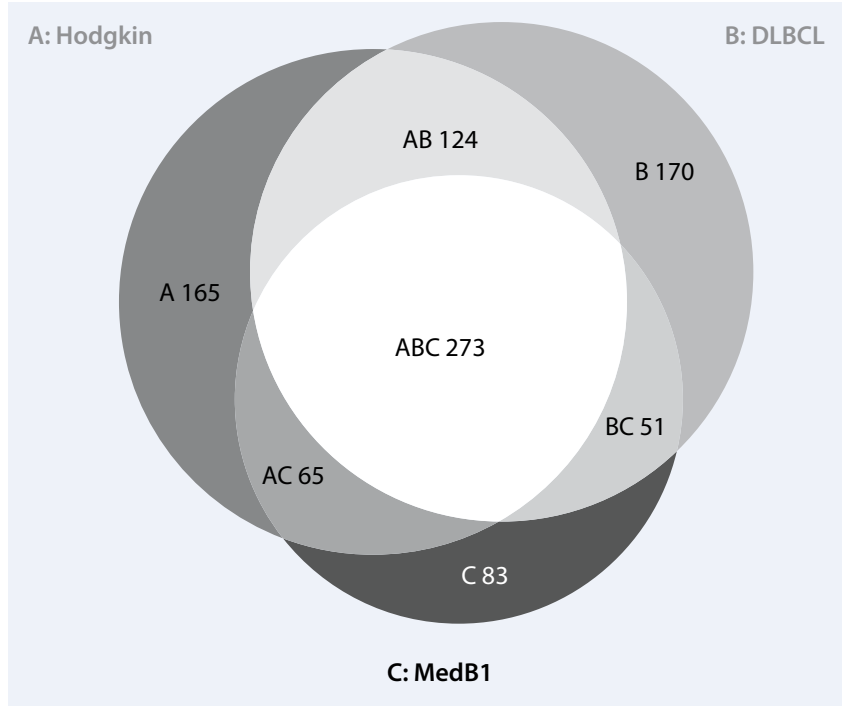

Fig. $1<$ Overlapping and differentially expressed TM proteins identified by CSC technology particularly challenging, because neoplastic cells largely share the same genome and proteome as normal cells. Microarraybased mRNA expression profiling experiments can roughly estimate the expression of a protein by measuring the protein encoding mRNA, but they cannot predict protein localization or post-translational modifications. In order to understand and unravel cancer biology at the molecular level, the PM protein composition as well as post- and co-translational modifications must be investigated directly. Since PM proteins are accessible for diagnostic and therapeutic intervention by antibodies or small moleculebased strategies, these protein targets are of the greatest interest as potential diagnostic and predictive markers.

Challenges to identifying the PM subproteome arise from the need to overcome the technical difficulties in isolating PM proteins, the limited relative abundance of PM proteins and the difficulty in resolving and identifying hydrophobic polypeptides. To address these issues, we have developed new methodologies for the specific labelling of proteins residing in the PM to circumvent the above-mentioned problems [8]. Our approach exploits the fact that most cell surface proteins are glycosylated. Glycosylation of PM proteins is a common co-translational modification [10]. The highly specific CSC technology utilizes a three-step tandem affinity la- 
belling strategy to confer the desired specificity for glycoproteins in the PM subproteomes. Results from model cell lines and from primary cells and tissues have yielded a degree of specificity never seen before in the detection of low-abundance PM proteins, with less than $10 \%$ contamination from intracellular and non-glycosylated peptides/proteins. The "contaminations" can be singled out in a bioinformatics approach, yielding $100 \%$ bona fide PM proteins. CSC technology uses the mass spectrometer as an "antibody" capable of specifically detecting PM glycoproteins that cannot currently be detected any other way.

\section{Materials and Methods}

Four HL cell lines of nodular sclerosing and mixed cellularity type, four diffuse large B cell lymphoma (DLBCL) lines of germinal centre and activated cell type and a mediastinal B cell lymphoma (MedB1) line were investigated via mass spectrometry by CSC technology. The cell surface proteomes of the cell lines were compared, and selected differentially expressed proteins were validated on the single cell level with affinity-based probes on a formalin-fixed and paraffin-embedded cell line array of the same set of cell lines. Validated protein targets are further analysed on newly established lymphoma TMAs from patient samples.

\section{Results}

A total of 747 predicted transmembrane proteins were identified in all cell lines, including 142 CD molecules (• Tab. 1). Many of the identified proteins are wellknown CD molecules such as CD19, $\mathrm{CD}_{20} \mathrm{O}$ and $\mathrm{CD}_{22}$ in the DLBCL lines or $\mathrm{CD}_{3} \mathrm{O}$ in the HL and MedB1 lines. CSC technology also revealed $\mathrm{CD}$ molecules that are low abundant in lymphoma tissue such as $\mathrm{CD}_{2}$ in the HL lines HDLM2 and L540. Whereas some of the transmembrane proteins are differentially expressed, others overlap between different lymphoma subtypes (• Fig. 1). Based on all identified predicted transmembrane proteins, unsupervised hierarchical clustering using SPOTFIRE software showed a cluster of DLBCL lines that was separated from the

Pathologe 2008 · [Suppl 2] 29:314-316 DOI 10.1007/s00292-008-1049-4

(c) Springer Medizin Verlag 2008

M. Tinguely · A. Hofmann · D. Bausch-Fluck · H. Moch · B. Wollscheid
Immunphänotypisierung ohne Antikörper.
Neue Perspektiven in der Lymphomcharakterisierung

Zusammenfassung

Ziel. Eine exakte Klassifikation hämatologischer Neoplasien ist Voraussetzung für eine korrekte Diagnose, Prognose und Therapiestrategie. Die Lymphomklassifikation war bis dahin limitiert durch die beschränkte Verfügbarkeit von Antikörpern gegen Oberflächenproteine, die in der Routinediagnostik an Paraffinmaterial anwendbar sind. Eine systematische und quantitative Analyse von Oberflächenproteinen ist notwendig, um neue Proteinmarker auf Lymphomsubtypen zu identifizieren.

Methode. Neun Hodgkin- und Non-Hodgkin-B-Zelllinien vom diffus großzelligen und mediastinalen Typ wurden mittels sog. "Cell surface capture" (CSC)-Technologie, einer massenspektrometriebasierten Methode, nach Zelloberflächenglykoproteinen untersucht. Selektionierte Proteine wurden mittels antikörperbasierter Methoden unter Einschluss von Durchflusszytometrie und Immunhistochemie auf Gewebechips validiert. Resultate. Insgesamt wurden 747 Transmembranproteine identifiziert, davon 142 CD- ("cluster of differentiation") anno- tierte Proteine. Mittels quantitativer CSCTechnologie wurde eine Gruppe unterschiedlich exprimierter Oberflächenglykoproteine zwischen Hodgkin- und Non-Hodgkin-B-Zelllinien nachgewiesen. Dabei wurden sowohl typische CD-Moleküle wie CD20 und CD30, aber auch weniger häufige Moleküle wie CD2 in Hodgkin-Lymphom- (HL-)Zelllinien identifiziert und mittels Immunhistochemie auf primären Zelllinien und Lymphomgewebe validiert. Ein Set von differenziell exprimierten Glykoproteinkandidaten wird aktuell auf Lymphomgewebechips untersucht. Schlussfolgerung. Die CSC-Technologie erlaubt, gleichzeitig mehrere hundert Oberflächenproteine auf Lymphomzelllinien nachzuweisen. Darüber hinaus können auch unbekannte, differenziell exprimierte Proteine identifiziert werden.

\section{Schlüsselwörter}

Zelloberflächenglykoproteine · "Cell surface capture" (CSC)-Technologie · Massenspektrometrie - Lymphom

\section{Immunophenotyping without antibodies. New perspectives for lymphoma characterization}

\section{Abstract}

Aims. Accurate classification of haematological malignancies is a prerequisite for their correct diagnosis, prognosis and therapy. Clear classification of lymphomas is often hindered by the limited number of available cell surface protein markers that are suitable for immunophenotyping. A systematic and quantitative analysis of cell surface proteins is thus required to identify new protein markers on lymphoma subtypes in an unbiased and discovery-driven approach.

Methods. Nine Hodgkin and non-Hodgkin B cell lines of diffuse large cell type and mediastinal type were investigated by cell surface capture (CSC) technology, a mass spectrometry-based method to identify cell surface glycoproteins. Selected proteins are verified by antibody-based methods, including flow cytometry and immunohistochemistry on cell line arrays.

Results. A total of 747 predicted transmembrane proteins were identified from all cell lines, including $142 \mathrm{CD}$ (cluster of differentiation) annotated proteins. A group of differentially expressed cell surface glycoproteins between Hodgkin and non-Hodgkin B cell lines was revealed via quantitative CSC technology. In addition to classical and expected CD molecules such as $C D 20$ and $C D 30$, less frequently expressed molecules such as $\mathrm{CD} 2$ on Hodgkin lymphoma $(\mathrm{HL})$ cell lines were identified by CSC and verified by immunohistochemistry in cell lines and primary lymphoma tissue. A panel of CSC-identified differentiation glycoprotein candidates is currently under investigation on tissue microarrays (TMAs) from patient samples.

Keywords

Cell surface glycoprotein markers · Cell surface capture (CSC) technology · Mass spectrometry $\cdot$ Lymphoma 
Tab. 1 Number of TM-predicted and

CD-annotated proteins identified in

Hodgkin's lymphoma, mediastinal large

B cell lymphoma and diffuse large B cell

lymphoma

$\begin{array}{lll}\text { Cell lines } & \begin{array}{l}\text { Number of } \\ \text { unique pre- } \\ \text { dicted TM and } \\ \text { GPI-anchored } \\ \text { proteins }\end{array} & \begin{array}{l}\text { Number of } \\ \text { unique CD } \\ \text { proteins }\end{array} \\ & & \end{array}$

\begin{tabular}{lll} 
HL_HDLM-2 & 332 & 85 \\
\hline HL_KMH-2 & 337 & 78 \\
\hline HL_L-428 & 445 & 80 \\
HL_L-540 & 348 & 87 \\
\hline K_MedB1 & 497 & 98 \\
NH_HBL-1 & 355 & 88 \\
NH_SU-4 & 359 & 80 \\
\hline NH_SUDHL-6 & 347 & 89 \\
NH_U2932 & 352 & 100 \\
\hline All records & 986 & 177
\end{tabular}

group of $\mathrm{HL}$ lines. In contrast, the MedB1 line was clearly split up with these two groups. Though the MedB1 line seems to be a distinct entity, it is more closely related to the HL than to the DLBCL lines. Together, the CSC data disclose the cell surface proteomes of HL, DLBCL and MedB1 lines in great detail and allow for novel insights into the functional capacities of these cells.

\section{Discussion}

CSC technology is a mass spectrometrybased technology that allows for the discovery-driven identification of cell surface proteins regardless of the availability of antibodies. The proteomic data generated correlate with findings from gene array analysis regarding the relatedness of Hodgkin's and mediastinal large B cell lymphoma (MedB1) cell lines [3, $1,6]$. Moreover, the CSC results revealed overlapping and differentially expressed known and unknown transmembrane proteins in the different cell lines. By validating differentially expressed proteins on the investigated cell lines and on primary lymphoma tissue, we aim to identify new specific markers to facilitate the differential diagnosis of lymphomas.

As we were recently also able to apply the CSC technology to primary tissue, subproteome-targeted proteomics opens up new perspectives for a refined classification of lymphomas and future potential targets for specific treatment approaches.

\section{Corresponding author \\ Dr. M. Tinguely \\ Institute for Surgical Pathology, \\ University Hospital Zurich \\ Schmelzbergstrasse 12, 8091 Zürich, \\ Switzerland \\ marianne.tinguely@usz.ch}

Conflict of interest. The corresponding author certifies that no actual or potential conflict of interest exists in relation to this article.

\section{References}

1. Calvo KR, Traverse-Glehen A, Pittaluga S, Jaffe ES (2004) Molecular profiling provides evidence of primary mediastinal large B-cell lymphoma as a distinct entity related to classic hodgkin lymphoma: implications for mediastinal gray zone lymphomas as an intermediate form of B-cell lymphoma. Adv Anat Pathol 11(5): 227-238

2. Jaffe E, Harris NL, Stein H, Vardiman W (2001) Pathology and genetics of tumours of haematopathopoietic and lymphoid tissue. iARC Press, Lyon

3. Rosenwald A, Wright G, Leroy K et al. (2003) Molecular diagnosis of primary mediastinal B cell lymphoma identifies a clinically favorable subgroup of diffuse large B cell lymphoma related to hodgkin lymphoma. J Exp Med 198(6): 851-862

4. Schwering I, Brauninger A, Klein U et al. (2003) Loss of the B-lineage-specific gene expression program in hodgkin and reed-sternberg cells of hodgkin lymphoma. Blood 101(4): 1505-1512

5. Tinguely M, Jenni B, Reineke T et al. (2007) Chromosomal translocations $\mathrm{t}(4 ; 14), \mathrm{t}(11 ; 14)$ and proliferation rate stratify patients with mature plasma cell myelomas into groups with different survival probabilities - a molecular epidemiologic study on tissue microarrays. Am J Surg Pathol 31(5): 690-696

6. Traverse-Glehen A, Pittaluga S, Gaulard P et al. (2005) Mediastinal gray zone lymphoma: the missing link between classic hodgkin's lymphoma and mediastinal large B-cell lymphoma. Am J Surg Pathol 29(11): 1411-1421

7. Vanhentenrijk V, Vanden Bempt I, Dierickx D et al. (2006) Relationship between classic hodgkin lymphoma and overlapping large cell lymphoma investigated by comparative expressed sequence hybridization expression profiling. J Pathol 210(2): 155-162

8. Wollscheid B, Busch-Fluck D, Henderson C et al. (under revision) Mass-spectrometric identification of cell surface proteins: immunophenotying without antibodies. Nat Biotechnol

9. Wollscheid B, Watts JD, Aebersold R (2004) Proteomics/genomics and signaling in lymphocytes. Curr Opin Immunol 16(3): 337-344

10. Zhang H, Aebersold R (2006) Isolation of glycoproteins and identification of their N-linked glycosylation sites. Methods Mol Biol 328: 177-185 